\title{
THE STUDY OF AGRICULTURAL MECHANIZATION INDICATORS IN EASTERN LIBYA
}

\author{
OBAIA, A. R.* and M.I. Ghazy **
}

\begin{abstract}
This investigation was carried out at Elmarj region eastern Libya to study the situation of mechanization and to determine degree, level, index of agricultural mechanization and cost analysis. The cultivation area, number of tractors and its power, machines and labors number, wheat crop yield, degree level, and index of mechanization were identified. Data showed that the average level of mechanization is equal to 0.53 $\mathrm{kW} / \mathrm{ha}$ and the mechanical support for production is $9.63 \mathrm{~kW} / \mathrm{labor}$. While, the mechanization degree recorded $2.40 \mathrm{~kW} \mathrm{h/ha}$ according to labor power. Similarly, mechanization degree of all activity found as $189.32 \mathrm{~kW}$ h/ha according to drawbar power. General agricultural operations for mechanization index was $43.56 \%$. The total calculated costs for tillage, seeding and harvesting operations were 19.14, 19.36 and $71.07 \mathrm{D} / \mathrm{h}$, respectively. Also, the total calculated costs for all operations in the study region was $108.68 \mathrm{D} / \mathrm{ha}$. The producing cost of one ton of wheat grain and straw under region study was 32.44 and $26.51 \mathrm{D} /$ ton respectively.
\end{abstract}

Keywords: Agricultural mechanization, Degree, Level, index of mechanization.

\section{INTRODUCTION}

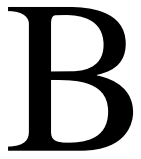
$y$ definition, the mechanization of agriculture is the "application of mechanical implements or as a whole, the application of the state-of-the-art technologies in agriculture to increase productivity and to reach sustainable agriculture". There are three specific indices for the study and evaluation of mechanization in different regions. These indices include degree, level, and capacity of mechanization (Almasi et al., 2000).

\footnotetext{
* Agric. Eng. Res. Institute, ARC, Dokki, Giza, Egypt. **Agric. Eng. Dept., Fac. of Agric., Mansoura Univ.
} 
Mechanization level may be assessed according to various criteria. Among the simplest and least controversial is the index of value of equipment per ha, which defines potential reserves. Also helpful are indices of energy inputs per ha and the value of power utilized per working hour. In a research, mechanization level of 47 farms (2-10 ha) was studied. On larger farms, mechanization level was 74 to 79 percent. More mechanization level, due to the size distribution of farms was not possible (Muzalweski, 1992).

Ozemerzi and Berek-Barut (1998) stated that the agricultural mechanization level of a country is technically expressed in terms of $\mathrm{HP} / \mathrm{ha}$ standard being of 1.5 to $2.0 \mathrm{HP} / \mathrm{ha}$. The results showed that, mechanization level was $1.73 \mathrm{~kW} / \mathrm{ha}$. It was higher than the global average. While, The relationship between mechanization level, size of farm and agricultural productivity was studied. Farms in the three groups, small, medium and large, were classified. Results showed that, each tractor, 3-4 months of the year are used for land preparation. In plowing, tractor field capacity $(60 \mathrm{~kW})$ was 0.5 to $1.5 \mathrm{ha} / \mathrm{h}$. Annual operating tractor ranged between 200-250 h. In plowing, fuel consumption tractor $(60 \mathrm{~kW})$ per ha was 10 to 15 litter (Saruth and Gee-Clough,1998).

In the field of mechanization of agriculture compared with developed countries, Bangladesh is still at a low level. $68 \%$ of the total power needed to pull tillage, funded by livestock. The total available labor power is 7.3 million HP. Machinery available power is $0.11 \mathrm{HP} / \mathrm{ha}$ (Salokhe and Ramalingam, 1998). In Kaboda - rahang, the mechanization level was $0.79 \mathrm{HP} / \mathrm{ha}$. Acceptable level of mechanization was found as $1.33 \mathrm{HP} / \mathrm{ha}$ with 1125 tractors had average power of 75 HP should be added (Abbasi, 2001).

Pishbin (2013) affirmed that, in mechanization science had two main indexes exist which are used for analyzing and evaluating condition of area in micro and macro levels. These indexes include mechanization level and capacity. Mechanization capacity is an index which is result of agricultural quality and quantity and is equal to the amount of 
consumed energy per unit of area. Mechanization level indicates the ratio of total tensional powers by under cultivated area. These two indexes are useful in analysis of existed situation of mechanization in regional, province and national levels. The degree of mechanization $(\mathrm{kW} \mathrm{h/ha)}$ is considered the mechanization capacity (kW.h/ha). Ismail and Ismail (2014) selected the suitable integrated machines for wheat production depending on the field area and available time for each operation. A Visual Basic program "WAMTLISH " is used to calculate the information from the wheat operating systems. This program is divided into three main subroutines to be worked on the main wheat production processes including; manure spreaders, tillage, leveling, irrigation, seeding, and harvesting to select machine number and specifications that recognized to give obtain the minimum operating time and cost.

On other hand, a simulation program based on timeliness of the operations performance for wheat production. It is adaptability to planting in different methods (sowing or drilling, broadcasting and transplanting). The time of harvesting also is changed relative to planting methods consequentially; the quality and the quantity of wheat production may be differ through a harvesting season. The results cleared that the correlation coefficients between the mean yield losses and operation starting of the late sowing period ranged from 0.95 to 0.985 , compared with 0.92 to 0.97 for the early period. The average time penalty loss for the planting operation were about 411.26 \pm 176.60 LE/fed and 427.35 $\pm 234.17 \mathrm{LE} /$ fed due to a crop being established too early and too late respectively. The best planting date that relating to the highest wheat crop is ranged from 14 to 21 November (Ismail et al. -2010).

Ismail and Abdel-Mageed (2010) study carried out to evaluate three harvesting systems based on machine and workability of the operations performance for wheat production. Three methods under study evaluated, namely: green combine-bagger or tank (first method; reaper + thresher (second method) and the manual (third method). The evaluation of harvesting systems involves a number of modeling approaches and the models fall into: The first is evaluating machine performance by 
measuring machine capacity and the labour requirement. The second parameter is workability, which calculated measuring the two mean factors, mainly, the length of harvesting period and potential harvesting hours. The third is economical evolution, which is dun calculating fixed costs, operating costs and optimal harvesting capacity. It is important that unproductive work minimized. Therefore, Optimum harvesting operations as well as good systems needed to minimize the cost and obtain maximum profits. The required of the labour number for three systems under studies were 5; 2; 15 and 23 labour per harvesting systems for combine with tank, combine with bagger, "reaper + thresher" and "manual + thresher" systems respectively. In addition, the total manual energy required "kWh/ton" recorded $0.8 \mathrm{kWh} / \mathrm{fed}$ while; it was about $6.73 \mathrm{kWh} / \mathrm{fed}$ for the manual system. Regarding to the purchase price of combine machine, the power per unite area is very small but the inertia cost is very height.

Ismail et al.(2009) studied the connection between draft and fuel consumption relative to the operation cost and machine selections and to evaluate the tractor-plough operation. For this reason, the tractor tire specifications and the chisel plough properties used by the visual basic program to calculate the fuel cost/fed at different tractor power, forward speed and plough width. The results showed that the suitable tractor could be used to tillage operation of $47.81 \mathrm{~kW}$ for all plough width and at different forward speed. Machinery costs make up a significant part of the fixed and variable costs of any farm operation. However, they are sometimes difficult to calculate, particularly for individual enterprises or operations. Effective machinery management is essential to maintaining profitability in production agriculture (Pflueger, 2005).

This investigation was carried out in Elmarj region in the province of East Libya to study the situation of mechanization in the region and to determine degree, level, index of agricultural mechanization and cost analysis.

\section{Study area}

\section{MATERIALS AND METHODS}

Elmarj region is considered the agricultural capital in Libya. It is concentrated where arable farms. These farms were divided into areas 
such as Aluweilia, Farzoughah, duck, Taknas, Tolmeita, Alabiar, Alkhawabi, Alahamdh. Elmarj is one of the bitter cold of the cities in Libya, and its climate is moderate warm in summer, bitterly cold in winter and snow has been falling. The soils in Elmarj (red soil) content of a calcareous abound with calcium carbonate and its ability to retain high water and is one of the most important arable land after reclamation and add fertilizers to make up for missing nutrients needed by the plant.

\section{Approach data methodology}

The data collection included nine area in Elmarj region for wheat crop production. In this study, the methods used for gathering data were questionnaire, interview, observation and gathering formal statistics. The study was conducted in two phases. Phase one involved a field survey. The second phase is the analysis of data using mechanization index approach, which determines the level and degree of farm mechanization.

\section{Determination of Mechanization Indexes}

\section{- Mechanization level}

The following equation is used to calculate mechanization level according to Pishbin (2013).

$$
M L=\frac{P_{m} \cdot C_{f}}{A}
$$

\section{- Mechanical support for production}

The following equation is used for calculating mechanical support for production according to Al-tahan (2008):

$$
M p=\frac{P_{m}}{N}
$$

\section{- $\quad$ Degree of mechanization (M1, kW.h/ha )}

The procedure for calculating human energy is similar to the previous one, but it should be taken into consideration that, firstly, to calculate the number of working population in agricultural sector, all people of the 
region including farmers and supporting people who play a role in crop production should be involved; secondly, a normal person can produce on average about $0.1 \mathrm{~kW}$ during a working day. Operations carried out exclusively by human power were determined according to (Ortiz-Canavate and Salvador, 1980):

$$
M 1=\frac{0.1(N . T)}{A}
$$

- $\quad$ Degree of mechanization (M2, kW.h/ha)

To calculate the mechanical energy, the first instruction has to be followed. The number of days machinery is used during a year should be noted according to the calendar, as well as the limitations of using machinery on some days. And the mean daily functional hours of machines are separately. Corresponds to use of machinery with mechanical energy source were determined according to (OrtizCanavate and Salvador, 1980):

$$
M 2=\frac{P_{m} \cdot T}{A}
$$

where;

$\mathrm{ML}=$ mechanization level $(\mathrm{kW} / \mathrm{ha})$

$\mathrm{p}_{\mathrm{m}}=$ Total power of tractors $(\mathrm{kW})$

$\mathrm{C}_{\mathrm{f}}=$ Convey coefficient (o.5 or 0.75 for waste and useful instruments respectively)

$\mathrm{A}=$ Total cultivated area under studied zone (ha)

$\mathrm{Mp}=$ mechanization level (kW/labor)

$\mathrm{N}=$ Number of labor.

$0.1=$ human power $(\mathrm{kW})$

$\mathrm{T}=$ time devoted to manual operations (h)

\section{- $\quad$ Mechanization index}

Mechanization index represents percentage of work done by machines, human efforts and machinery was calculated using the relationship below according to Olaoye et al. (2014): 


$$
M I=\frac{L m}{(M 2+L m)} \times 100
$$

where;

$\mathrm{MI}=$ Work done by machines obtained by summing up all the work outlay by human and machines.

$\mathrm{LM}=\mathrm{M} 1+\mathrm{M} 2$

\section{Estimating farm machinery costs}

\section{Fixed Costs}

\section{a) Depreciation}

Declining balance method was used to determine the depreciation (Hunt, 1983). In this method the depreciation value is different for every year of the machines life. Depreciation value was determined by using the following equation:

$$
\begin{aligned}
& D=V_{n}-V_{n+1} \\
& V_{n}=P\left(\frac{L-X}{L}\right)^{n} \\
& V_{n+1}=P\left(\frac{L-X}{L}\right)^{n+1}
\end{aligned}
$$

\section{Where:}

$\mathrm{D}=$ value of depreciation charged year, $(\mathrm{n}+1), \mathrm{D} / \mathrm{Yr}$;

$\mathrm{P}=$ purchase price, $\mathrm{D}$;

$\mathrm{L}=$ time between buying and purchasing, Yr.;

$\mathrm{N}=$ number representing age of the machine in year at the beginning of year;

$\mathrm{V}=$ remaining value at any time and

$\mathrm{X}=$ ratio of depreciation rate for used machine (the maximum rate is 1.5).

b) Interest on investment, shelter taxes and insurance

They were estimated as $12 \%$ of the remaining value. 


\section{Operating Costs}

\section{- $\quad$ Fuel, Lubrication and Labor}

The standard equation to calculate specific volumetric fuel consumption

use was estimated using the ASABE formula (ASABE, 2007)

$$
S F C=2.64 X+3.91-0.203 \sqrt{738 X+173}
$$

Where:

$\mathrm{SFC}=$ specific fuel consumption, $\mathrm{L} / \mathrm{kW} . \mathrm{h}$

$\mathrm{X}=$ the ratio of the equivalent PTO power required for an operation, to the maximum available from the PTO.

\section{- $\quad$ Lubrication}

According to Nebraska Tractor Test data, a general rule of thumb can be applied for estimating the cost of lubrication. The rule of thumb that is applied for power machinery is $15 \%$ of fuel costs. For nonpower equipment $5 \%$ of the purchase price is used.

\section{- Labor}

Labor cost is calculated using the cost of labor per hour. Labor hours per acre are based on field capacity of machinery.

\section{- Calculation of repairs and maintenance costs}

The calculation of the repair costs of tractors and agricultural machines was calculated according to (Lorencowicz and Uziakb, 2015).

$$
K_{n}=\frac{C_{m} \cdot r \cdot x}{W_{r}}
$$

\section{Where:}

$\mathrm{K}_{\mathrm{n}}=$ repair unit cost $(\mathrm{D} / \mathrm{h})$

$\mathrm{C}_{\mathrm{m}}=$ list price of the machine (D)

$r=$ repair cost coefficient, 
$\mathrm{x}=$ repair cost correction factor

$\mathrm{WT}=$ estimated life $(\mathrm{h})$

\section{RESULTS AND DISCUSSIONS}

From the analysis of the returned questionnaires, the outcome showed that of the 100 questionnaires administered and these were used for the purpose of analysis. The cultivated area ranging between 10-25 hectares ratio estimated at 3\%, cultivated and space ranging between 25-50 hectares estimated at $35.5 \%$, cultivated and space ranging between 50-75 hectares estimated at 50\%, while the cultivated area, which ranging from 75-130 hectares estimated at 11.5\%. Also show that, the personal interview to some farmers that most of the tractors and agricultural machines have been distributed to farmers by the state, in the period from 1979 to 1985, almost at the rate of one tractor, chisel plow, mouldboard plow, seeders per farm. The types of tractors is Massey Ferquson 185 industry either French or Spanish or England and the second type, a tractor track German industry.

The recording data of working area, number of tractor, tractor power and number of labor were recorded for Elmarj region and summarized in Table (1). As shown in Table (1) the total of working area, total number of tractor, and total number of labor were 5335 ha, 182 and 291, respectively. The average tractor power was found to be $62 \mathrm{~kW}$ with an average one tractor for every 30 hectares.

Table 1. The working area and number of tractors and labor in the Elmarj region.

\begin{tabular}{|l|c|c|c|c|}
\hline Statement & $\begin{array}{c}\text { Working } \\
\text { area (ha) }\end{array}$ & $\begin{array}{c}\text { Number of } \\
\text { tractor }\end{array}$ & $\begin{array}{c}\text { tractor } \\
\text { power } \\
\text { (kW) }\end{array}$ & $\begin{array}{c}\text { Number } \\
\text { of labor }\end{array}$ \\
\hline Minimum & 15 & 1 & 20 & 1 \\
\hline Maximum & 130 & 5 & 71 & 10 \\
\hline Total & 5335 & 182 & 6166 & 291 \\
\hline
\end{tabular}

Table (2) illustrates the kind of implement in east Libya region. The table shows that the total number of plowing, sowing and harvesting implements were 164, 153 and 63 respectively.

Table (3) illustrates the field capacity and field efficiency for tillage, 
seeding and harvesting based field operation. The effective field capacities in the Table (3), can be used as estimates of machine capacity under average field conditions. The field capacity estimated $0.68,0.78$ and $1.17 \mathrm{ha} / \mathrm{h}$ for plowing, sowing and harvesting, respectively. Also, field efficiency is expressed as the percentage of a machine's actually achieved under real conditions. The field capacity estimated 82, 65 and $73 \mathrm{ha} / \mathrm{h}$ for plowing, sowing and harvesting, respectively.

Table 2. The number of kinds of implement in the Elmarj region.

\begin{tabular}{|l|c|c|c|}
\hline Statement & $\begin{array}{c}\text { Number of } \\
\text { plowing } \\
\text { implement }\end{array}$ & $\begin{array}{c}\text { Number of } \\
\text { sowing } \\
\text { implement }\end{array}$ & $\begin{array}{c}\text { Number of } \\
\text { harvesting } \\
\text { implement }\end{array}$ \\
\hline Minimum & 1 & 1 & 1 \\
\hline Maximum & 4 & 5 & 3 \\
\hline Total & 164 & 153 & 63 \\
\hline
\end{tabular}

Table 3. Field capacity and field efficiency based operation in the Elmarj region.

\begin{tabular}{|l|c|c|}
\hline Field operation & Field capacity $(\mathbf{h a} / \mathbf{h})$ & $\begin{array}{c}\text { Field efficiency } \\
(\boldsymbol{\%})\end{array}$ \\
\hline tillage & 0.68 & 82 \\
\hline seeding & 0.78 & 65 \\
\hline harvesting & 1.17 & 73 \\
\hline
\end{tabular}

According to definition of mechanization level which is an important factor in macro and micro policy and decision making in the field of province agriculture, this faction was considered in different cities of province. To investigate the mechanization level which is, in fact, per capital power in terms of $\mathrm{kW}$ per hectare, it was first of all necessary to determine the number of all kinds of active tractors in the region which are used as the source of draft power. According to Equation (1), since the arable area of the region is 5335 hectares, the mechanization level in Elmarj region estimated $0.53 \mathrm{~kW} / \mathrm{ha}$, it is lower than world mean. Also, According to Equation (2), the mechanical support for production is $9.63 \mathrm{~kW} / \mathrm{labor}$. 
According to labor power, mechanization degree in Elmarj region was $2.40 \mathrm{kWh} / \mathrm{ha}$, according to Equation (3). Also, according to drawbar power, mechanization degree or mechanization capacity of all activity was $189.32 \mathrm{kWh} / \mathrm{ha}$, according to Equation (4). In studying the mechanization index was $43.56 \%$ according to Equation (5).

\section{Cost analysis}

This indicator reflects what accomplish mechanization of economic fled for some agricultural operations under current circumstances. As shown in Table (4) the total calculated costs for tillage, seeding and harvesting operations were $19.14,19.36$ and $71.07 \mathrm{D} / \mathrm{h}$, respectively. Also, the total calculated costs for all operations in the study region was $108.68 \mathrm{D} / \mathrm{ha}$. The cost of producing one ton of wheat grain in the study region was $32.44 \mathrm{D} /$ ton making break-even yield to be 3.350 tons/ha. Also, the cost of producing one ton of wheat straw in the study region was $26.51 \mathrm{D} /$ ton making break-even yield to be 4.100 tons/ha.

Table 4. Total cost based operation in the Elmarj region.

\begin{tabular}{|l|c|c|}
\hline \multicolumn{1}{|c|}{$\begin{array}{c}\text { Implement and } \\
\text { operation }\end{array}$} & $\begin{array}{c}\text { Total cost } \\
(\mathrm{D} / \mathrm{h})\end{array}$ & $\begin{array}{c}\text { Total cost } \\
(\mathrm{D} / \mathrm{ha})\end{array}$ \\
\hline tractor & 10.62 & --- \\
\hline Chisel plow & 2.33 & --- \\
\hline Tillage operation & 19.14 & 25.73 \\
\hline Drill & 4.48 & --- \\
\hline Seeding operation & 19.36 & 22.10 \\
\hline Harvesting operation & 71.07 & 60.85 \\
\hline
\end{tabular}

\section{CONCLUSION}

From this study the following conclusions can be made:

1. The field capacity in Elmarj region estimated 0.68, 0.78 and $1.17 \mathrm{ha} / \mathrm{h}$ for tillage, seeding and harvesting, respectively. The field capacity estimated 82,65 and $73 \mathrm{ha} / \mathrm{h}$ for tillage, seeding and harvesting, respectively.

2. The mechanization level in Elmarj region estimated 0.53 $\mathrm{kW} / \mathrm{ha}$, it is lower than world mean. The mechanical support for 
production is $9.63 \mathrm{~kW} /$ labor.

3. The labor power relative to mechanization degree recorded of $2.40 \mathrm{kWh} / \mathrm{ha}$. While, drawbar power relative to mechanization capacity of all activity in Libya of $189.32 \mathrm{kWh} / \mathrm{ha}$ and the mechanization index of $43.56 \%$.

4. The total costs for tillage, seeding and harvesting operations were $19.14,19.36$ and $71.07 \mathrm{D} / \mathrm{h}$, respectively. The cost of producing one ton of wheat grain and straw were 32.44and $26.51 \mathrm{D} /$ ton respectively.

\section{REFERENCES}

Abbasi S. (2001). Assess the present situation and provide appropriate solutions for agricultural mechanization in the Kabodar-ahang. Master's Thesis. University of Tabriz.

Almasi, M., Kiani, S. and Louimi, N. (2000). Principles of Agricultural Mechanization. Ma'soumeh (PBUH) Publication.Ghom, Iran. P. 19-40.

Altahan, Y.H. (2008). Study of Some Economical Criteria Evaluation Through Using Different Mechanization Systems Under Semi Arid Condations. Mesoppotamia J. of Agric., Irak, Vol. (36) No. (4), P:1-6.

ASABE. (2007). Standards. Agricultural machinery management (D496.3 Feb.2006) and Agricultural machinery management data (D797.4) and (D497.5) p $356 \&$ 362. American Society of Agricultural Engineers, St Joseph. Michigan, USA.

Hunt, D. (1983). Farm power and machinery management. eighth Edition. Iowa State Univ. Press, Ames., U.S.A.

Ismail, Z. E and W.T. Ismail (2014). Construction of "WAMTLISH" program to integrate machines for wheat production. Misr J. Ag. Eng., 31 (1): $1-18$.

Ismail, Z.E.; A.E. Abou-Elmagd and A.E. Abdel-Mageed (2010). Timeliness Costs In Wheat Production Systems. Misr J. Ag. Eng., 27 (1): $75-89$ 
Ismail, Z.E.; M.M. Ibrahim and S.A. Embaby (2009). Economic evaluation and selection of farm machinery. Misr J. Ag. Eng., 26(4): 746-757.

Ismail, Z.E.1 and A.E. Abdel-Mageed 2 (2010). Workability and machinery performance for wheat harvesting. Misr J. Ag. Eng., 27 (1): $90-103$.

Lorencowicz, E. and J. Uziak (2015). Repair cost of tractors and agricultural machines in family farms. Agriculture and Agricultural Science Procedia 7 ( 2015 ) P:152 - 157.

Muzalweski A. (1992). Choice of mechanization level criteria in researching the efficiency of private farms. ZeszytyProblemowe- Postepow-Nauk- Rolniczych. 2 (403), P: 189195.

Olaoye, J. O., Amusa and T. A. Adekanye (2014). Evaluation of the Degree of Agricultural Mechanization Index on the Performance of Some Farm Settlement Schemes in Southwestern Nigeria. Proceedings of the International Soil Tillage Research Organization (ISTRO) Nigeria Symposium, Akure 2014 November 3 - 6, Akure, Nigeria, P: 125 -133.

Ortiz-Canavate., and .I. Salvador (1980). Effects of Different Mechanization Levels in Spanish Dryland Farms. Journal of Agricultural Mechanization in Asia.3(5), P: 31-36

Ozemerzi A, Berek-Barut Z. (1998). Mechanization level, in vegetable production in Antalya region and Turkey. A.M.A. 29 (1), P: $32-$ 36.

Pflueger, B. (2005). How to Calculate Machinery Ownership and Operating Costs. South Dakota State University. Extension Circulars. Paper 485, P: 1-6.

Pishbin, S. (2013). Measurement of indexes agricultural mechanization in agriculture and horticulture crops in Fars Province. International Journal of Biosciences (IJB). Vol. 3, No. 12, p: 81-89. 
Salokhe, V. M. and Ramalingam, N. (1998). Agricultural Mechanization in the South and Southeast Asia. International Conference of the Philippines. Society of Agricultural Engineers, Las Banos, Philippines, 21-24 April, P: 1-23.

Saruth C, Gee-Clough D. (1998). Agriculture mechanization in Cambodia: A case study in Takeo province. A. M. A. 29 (2).

\section{الملخص العربي \\ دراسة مؤشرات الميكنة الزراعية فى شرق ليبيا \\ * عبدالو هاب رمضان عبيه و * *محمد إبراهيم غازى}

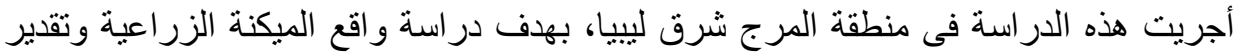

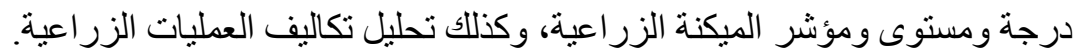

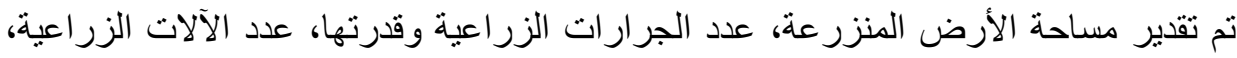

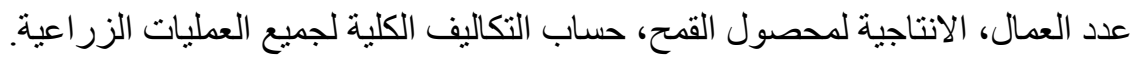

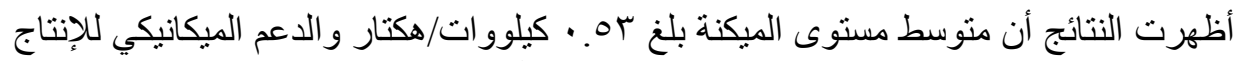

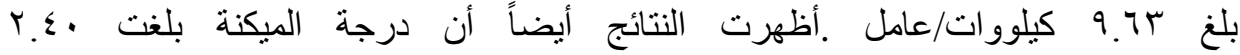

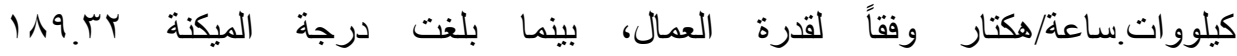
كيلووات.ساعة/هكتار وفقاً لقدرة الجرارات التهارة بينت النتائج أن مؤشر الميكنة لجميع العمليات

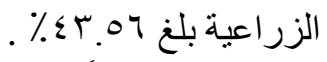

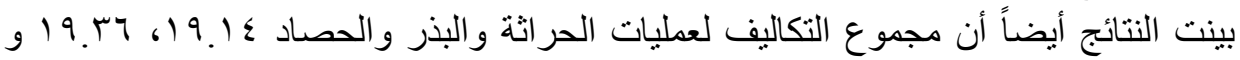

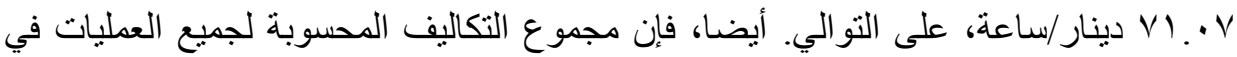

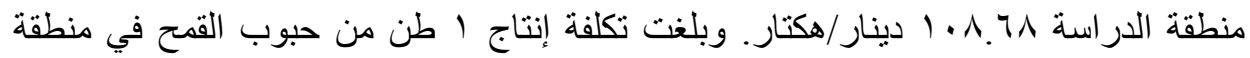

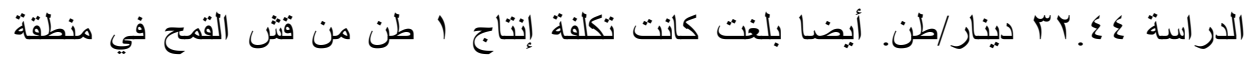

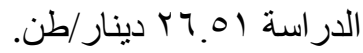

$$
\text { "باحث أول - معهد بحوث الهندة الزراعية - الاقى - الجيزة. }
$$
** مدرس - قسم الهندة الزراعية - كلية الزراعة - جامعة المنصورة. 